\title{
On exhibit
}

\author{
Darwin \\ An exhibition at the American Museum of Natural History \\ New York, New York, USA. \\ November 19, 2005-May 29, 2006. \\ Curated by Niles Eldredge. \\ Reviewed by Jonathan Gitlin \\ Washington University School of Medicine, St. Louis, Missouri, USA. \\ E-mail: gitlin@kids.wustl.edu
}

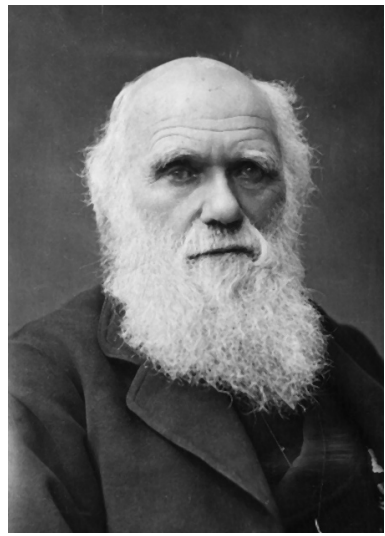

arwin is the title of a current exhibition at the American Museum of Natural History in New York. Perhaps the most surprising and certainly the most satisfying feature of this extraordinary exhibit is that it is at its core not about evolution but instead the evolution of Charles Darwin. Much has been written about Darwin, and one could reasonably argue that the facts of his life are readily in evidence. So who needs Darwin? Evolution remains today a controversial idea, and more opportunities, including this exhibition, are needed to provide the incontrovertible evidence that life on Earth has evolved. Yet Darwin transcends these issues, providing insight into the much more intriguing question of human creativity that is at the heart of all scientific discovery. Indeed, it is this intimate view into the essential process of wonder that makes the Darwin journey worthwhile.

So what was the road map to the greatest idea in biology? Walk into this exhibition and you are immediately confronted with the answer in the simplest form: a beetle beneath a looking glass. Darwin was curious about the world around him. Circumstances conspired such that he was fortunate enough to find the company of those who thought this curiosity alone enough to warrant support. In a remarkable compilation of Darwin's letters, we watch as the process of discovery begins. Aboard the Beagle less than a year, exploring the Brazilian rainforest, the 22-year-old Darwin sends back the first of a myriad of shipments of specimens to John Stevens Henslow, the Cambridge geologist who taught him and secured him passage, explaining that as he con- fronts what he sees, "the mind is a chaos of delight." The game was afoot, and Darwin observed, collected, and wondered. We see his struggle to come to terms with what is before him, his intuitive grasp of observations, and his penchant for data and detail.

From reading these letters, there can be no doubt that Darwin returned home in 1836 convinced that life evolved. In the next few years, he refines his ideas, seeks careful understanding of his specimens from experts, and begins in a series of notebooks to outline what he calls "my theory." Nevertheless, he is discontented by the fact that this theory lacks a mechanism until he reads the work of the conservative social economist Thomas Malthus. Now, in the class struggle of the Industrial Revolution, Darwin grasps what has previously eluded him: "the final cause of all this wedging must be to sort out proper structure and adapt it to change - to do that, for form, that Malthus shows, is the final effect of this populousness, on the energy of Man." "It is a contest," he writes, "and a grain of sand turns the balance." He has it - variation and natural selection.

It is at this point that Darwin provides the intimate and fascinating details of Darwin's struggle with the knowledge that, as he writes to botanist Joseph Hooker, revealing his ideas would be "like confessing a murder" to the Christian orthodoxy that is his society. He fears scientific ridicule from his colleagues, and on a deeply personal level cannot bear to disappoint his beloved wife, Emma, who wishes only to be with him throughout eternity. So he waits and he wonders and he worries and he walks and he writes for nearly 20 years, till one day a manuscript arrives. On his desk sits a precise and accurate account of the theory of evolution sent to him by Alfred Russel Wallace. Darwin is devastated that "all my originality, whatever it may amount to, will be smashed" and he will be denied his "proper place" among the men of science. Yet even as his life's work is preempted, he writes to his friend Charles Lyell regarding Wallace that "I shall at once write and offer to send to any journal." Here is the true measure of the man.

Of course his friends would have none of it, and the works were published together. We recognize Darwin today as the father of evolution because he collected the data to support his theory, and much of this is on display in this exhibition. Live tortoises, a fossil of the extinct giant glyptodont, horned frogs from South America, a reconstructed outcrop of a Galapagos island, and a replica of Darwin's Down House study are but a few of the delights awaiting the museum explorer. The "endless forms most beautiful” that became Darwin's record of evolution are all on display along with the extensive notes he made as he discovered the "grandeur in this view of life." Still, it is Darwin's story that ultimately holds our interest and in the final analysis makes clear the road map to all discovery - allow curiosity to flourish. So who needs Darwin? We all do, and thanks to the extraordinary stewardship of Niles Eldredge and the national treasure that is the American Museum of Natural History, we can have him in all his wonder. Go and see it now. 